DOI: $10.31249 / \mathrm{rsm} / 2018.03 .02$

\title{
B.В. Дамье
}

\section{РУССКИЙ ГЕНЕРАА И КИТАЙСКИЕ РААИКААЫ}

Аннотация. В статье речь идет о деятельности генерала А.С. Потапова - одной из самых загадочных и авантюрных фигур в истории Великой российской револючии. Историки до сих пор спорят о том, кем был этот человек и какую роль он сыграл в Февральской револючии, гражданской войне на Дальнем Востоке и первых попьтках установления советско-китайских отношений. В то же время рассказ о его приключениях и контактах в Китае позволяет пролить свет на малоизвестные перипетии идейно-организационной эволюции китайских левых движений в 1910 1920-х годах и на особенности восприятия российской революции в Китае.

Ключевые слова: Китай, Россия, А.С. Потапов, Сунь Ятсен, Чэнь Цзюнмин, Лян Бинсянь, анархисты, сочиалисты, большевики, русская эмиграция, Англобурская война, Русско-японская война, Первая мировая война, Великая российская револючия, Февральская револющия, Гражданская война, Дальний Восток.

Дамье Вадим Валерьевич - доктор исторических наук, ведущий научный сотруднк Института всеошей истории РАН, Москва. E-mail: vaddam@mail.ru

\section{V.V. Damier. The Russian General and Chinese Radicals}

Abstract. The article deals with the activities of General A.S. Potapov, one of the most mysterious and adventurous figures in the history of the Great Russian Revolution. Historians are still discussing who this man was and what role he played in the February Revolution, the Civil war in the Far East and the first attempts to establish Soviet-Chinese relations. At the same time, the story of his adventures and contacts in China allows to shed light on the little-known ups and downs of the ideological and organizational evolution of the Chinese leftist movements in the 1910-1920s and on the peculiarities of the perception of the Russian revolution in China.

Keywords: China, Russia, A.S. Potapov, Sun Yat-sen, Chen Jungming, Liang Bingxian, Anarchists, Socialists, Bolsheviks, Russian Emigration, Anglo-Boer War, RussoJapanese War, First World War, Great Russian Revolution, February Revolution, Civil War, Far East. 
Damier Vadim Valerievich - Doctor of History,

Leading Researcher on Institute of General History

of Russian Academy of Sciences, Moscow. E-mail: vaddam@mail.ru

25 ноября 1920 г. в Москву вернулся из эмиграции на Дальнем Востоке бывший генерал-майор Алексей Степанович Потапов. Он представил подробный отчет в Наркомат иностранных дел о своей деятельности и встречах в Китае и передал советским властям различные документы на китайском и корейском языках, в числе которых были письма к Ленину и лидерам Советского правительства от южнокитайских военных лидеров - генералов Чэнь Цзюнмина и Ли Лецзюня - и от Союза рабочих Китая, обращение генерала Чэня к китайским рабочим в России, мандаты, выданные Потапову китайскими организациями, удостоверения китайским делегатам, направленным в советскую Россию, и даже тексты революционных первомайских воззваний, которые помогал сочинять в Китае русский генерал... Сотрудники НКИД перевели доставленные материалы и передали копии переводов в Президиум Коминтерна [15].

Генерал Потапов был не просто одним из немалого числа высокопоставленных офицеров бывшей Русской императорской армии, которые в конечном счете перешли на сторону новой большевистской власти. За его спиной к этому времени осталась авантюрная и извилистая карьера, которая в любом случае делала 48-летнего «возвращенца» достаточно заметной фигурой даже в те бурные, полные потрясений и приключений годы войн и революций. Родившийся в 1872 г. в дворянской семье под Петербургом, он обучался в Императорской Военно-медицинской академии, на курсах Киевского пехотного юнкерского училища и в Николаевской академии Генерального штаба. В 1897 г. Потапов был произведен в поручики, в 1899 г. - в штабс-капитаны; его прикомандировали к войскам Петербургского военного округа, но в том же году направили в Южную Африку в качестве неофициального военного агента (формально он был на это время переведен в запас). Во время Англобурской войны его взяли в плен англичане, но затем освободили как подданного нейтрального государства. После возвращения в Россию в 1900 г. он был зачислен в лейб-гвардии Волынский полк, а затем направлен в Приамурский военный округ с присвоением чина капитана. По некоторым сведениям, ему пришлось принимать участие в подавлении восстания ихэтуаней в Китае. В 1902-1903 гг. Потапов командовал ротой в Приамурье, а в 1903 г. получил назначение русским военным агентом в Корее со званием подполковника. В 1904-1905 гг. молодой офицер активно участвовал в Русско-японской войне в Маньчжурии, закончив ее штаб-офицером 2-й Кубанской бригады, с которой и эвакуировался в Россию. В последующие годы Потапов служил в кавалерии на Кавказе, был начальником штаба 2-й пехотной дивизии 
в Белоруссии, 8-й кавалерийской дивизии в Бессарабии и 47-й пехотной дивизии в Поволжье. В 1908 г. ему присвоили звание полковника, но в 1912 г. уволили в запас по болезни в чине генерал-майора [33].

С началом Первой мировой войны генерал-майор Алексей Потапов был возвращен в строй и отправлен на германский фронт. В «верхах» его недолюбливали. Прибалтийский генерал-губернатор Павел Григорьевич Курлов ехидно замечал, что Потапова отставили по причине «умственного помешательства», и называл «бестактной» и неуместной его речь перед латышами, в которой тот призвал латышский народ сражаться против Германии $[19$, глава XXI]. Адмирал Василий Альтфатер сетовал, что у генерал-майора «абсолютно отсутствовали способности к организации». В марте 1915 г. наспех сформированный 10-тысячный отряд под командованием Потапова (на правах начальника дивизии) неожиданным ударом с налета захватил немецкий город Мемель в Восточной Пруссии (ныне - литовская Клайпеда). Немецкий гарнизон отступил, но затем к порту были подтянуты германские части; русские войска откатились назад и отступали до Либавы. Операция обернулась авантюрой [17]. В последующем Потапов командовал отдельной Сибирской казачьей бригадой, участвовавшей в Свенцянской операции, затем - Сибирской казачьей дивизией и, наконец, - одной из бригад 64-й пехотной дивизии [1, c. 305-306].

В революционные февральские дни 1917 г. мы обнаруживаем Алексея Потапова в Петрограде. Перешедший на сторону революции генерал-майор становится ближайшим сотрудником председателя Военной комиссии Временного комитета Государственной думы А.И. Гучкова. 1 марта он назначается заместителем председателя комиссии, а 4 марта - ее председателем, занимая этот пост до начала апреля 1917 г. [24, с. 253]1. В этой должности ему пришлось поддерживать нелегкие отношения с исполкомом петроградского Совета рабочих и солдатских депутатов, который выпустил знаменитый «Приказ № 1» об избрании военных комитетов в частях, разоружении офицеров и исполнении военных приказов только в тех случаях, когда они не противоречат постановлениям Совета. Приказ встретил резкие возражения со стороны Временного комитета Госдумы. Для разрешения возникшего кризиса

\footnotetext{
1. В исторических исследованиях до сих пор нередко можно обнаружить путанииу: некоторые авторы называют главой Военной комиссии не генерал-майора А.С. Потапова, а генерал-лейтенанта Николая Михайловича Потапова, начальника эвакуационного отдела Главного управления Генерального штаба, а с апреля 1917 г. генерал-квартирмейстера, позднее перешедшего на сторону большевиков и ставшего после Октября начальником Генштаба [см., напр.: 5, с. 322; 35, с. 557; 22, с. 48; 36, c. 453; 40, с. 110; 10, с. 343 и др.]. Эта ошибка или неопределенность повторялась и рядом зарубежных исследователей [см.: 56, с. 231-232, 397; 48, с. 429; 49, с. 81; $u$ op.].
} 
была организована встреча между сторонами. Делегация Совета прибыла на квартиру военного министра Гучкова. Как вспоминал Потапов, «заседание было очень бурным. Требование делегации Гучков признал для себя невозможным и несколько раз выходил, заявляя о сложении с себя звания министра. С его уходом я принимал председательствование, вырабатывались соглашения, снова приглашался Гучков, и заседание закончилось воззванием, которое было подписано от Совдепа Скобелевым, от комитета Гос[ударственной] Думы мною и от правительства Гучковым. Воззвание аннулировало приказы № 1 и № 2, но военный министр дал обещание проведения в армии более реальных, чем он предполагал, реформ по введению новых правил взаимоотношений командного состава и солдат» [цит. по: 12, с. 87; ср.: 21, с. 495-496].

Сам Потапов, по воспоминаниям генерала А.С. Лукомского, именовал себя «первым революционным генералом» [цит. по: 2, с. 40]. Но в реальности его посреднические действия вызывали только недовольство. Так, начальник Генерального штаба генерал П.И. Аверьянов отзывался о нем как об «одиозном» авантюристе: это «был просто больной, ненормальный и почти “невменяемый” человек, с которым военный министр А.И. Гучков не знал впоследствии, как и разделаться, как его сплавить не только из Петрограда, но даже вообще из России» [цит. по: 8, с. 229]. В конце концов после ликвидации Военной комиссии, в апреле 1917 г. Потапов остался генералом для поручений при военном министре, а летом того же года был назначен в резерв чинов при штабе Петроградского военного округа [9, с. 483].

Крах старой армии и революционные бури побудили генерал-майора Потапова на время отойти от активной деятельности и раздобыть командировку на Дальний Восток. Но уже в феврале 1918 г. генерал-лейтенант Алексей Павлович Будберг (будущий военный министр в правительстве адмирала А.В. Колчака) застает его в Харбине за политическими интригами и именует «полусумасшедшим авантюристом» [3, с. 284]. Встретившись в мае с Будбергом, Потапов долго разглагольствовал «о своих богатствах и о своей великой революционной роли». Он критиковал А.Ф. Керенского за то, что тот не назначил его военным министром Временного правительства, и ругал харбинские эмигрантские круги. Наконец, он поведал, что существует план сформирования Дальневосточного правительства, но Будберг отказался участвовать во власти, которая «попробует обосноваться на эсеровщине» [3 a, с. 206-207]. В июне 1918 г. Потапов, обитавший в харбинской гостинице вместе с Л.Н. Скипетровым, посланником лидера забайкальского «белого» движения атамана Г.М. Семёнова, предлагал Будбергу занять должность командующего войсками Амурской области при амурском казачьем атамане И.М. Гамове, но вновь получил отказ [3 а, с. 218]. В сентябре генерал-майор прибыл во Владивосток, где в тот момент решался вопрос об организации «белой» власти на Востоке России [3 a, с. 253]. После переворота Колчака Потапов перешел 
в оппозицию к власти верховного правителя. Перебравшись в Японию, он в 1919 г. предпринимал там усилия с тем, чтобы Колчак «полетел кувырком, и чтобы все попытки к признанию омской власти закончились неудачей» $[4$, c. 271]. Дело кончилось тем, что японские власти выслали его из страны.

17 декабря 1919 г. генерал обосновался в Шанхае, где пробыл до 22 апреля следующего года [46, с. 90]. В этом крупнейшем городе Китая, который в те годы служил не только международным центром, но также средоточием политической активности и всевозможных интриг, Потапов развернул поистине лихорадочную деятельность. Разругавшись с русскими «белыми» и японскими властями, он объявил себя приверженцем советской власти и сторонником большевиков. Более того, он стал уверять, что выполняет для советской России важную внешнеполитическую миссию.

«Генерал Потапов выдает себя за большевика и за жертву, принесенную на алтарь русской революции», - информировал генерального консула США в Шанхае Э. Каннингэма американский журналист Дж. Сокольский, близкий к Сунь Ятсену. Информатор утверждал, что Потапов выступал на стороне Л. Корнилова и «действовал против революционных войск» во время корниловского мятежа в 1917 г., бежал на Дальний Восток, а затем, «будучи вовлеченным в большевистскую пропаганду в Японии, он имел там неприятности, однако не думаю, чтобы он предпринял что-либо существенное», добавлял журналист. Сокольский считал генерала авантюристом и самозванцем: «Он неврастеник, страдает манией преследования и чрезмерным самомнением о важности собственной персоны. Он даже высказывается в том смысле, что может осуществлять контакты с Москвой даже в тех случаях, когда это не в состоянии сделать Владивостокское Земство ${ }^{2}$; он то и дело раздает рекомендательные письма к Ленину, которые затем под тем или иным предлогом забирает обратно. Он посетил д-ра Сунь Ятсена, с которым обсуждал планы сотрудничества Гоминьдана с большевиками. Однако он признает, что не имеет на то полномочий. Я предложил помочь ему при условии, если он предъявит мне свой мандат, но такового у него не оказалось. Он сам сказал мне об этом. Его говорливость стала причиной того, что широко распространились слухи о большевистской пропаганде в Шанхае». Но, подытоживал Сокольский, «Потапова не следует воспринимать всерьез, да никто и не принимает, если не считать газетчиков, столь падких на рассказы о большевиках» $[16$, с. 155].

2. Речь идет о правительстве Приморской областной земской управы, которое было образовано во Владивостоке после свержения режима адмирала Колчака в январе 1920 г. и просуществовало до декабря того же года. Поддерживалось большевиками, социалистами-революичонерами, меньшевиками, народными социалистами и профсоюзами [38]. 
Действительно, генерал встречался с Сунь Ятсеном и был скорее разочарован итогами их разговоров. Как он писал в докладной записке наркому по иностранным делам Г.В. Чичерину после своего возвращения в Россию, китайский политик в ходе бесед «неоднократно высказывал недоверие к возможности нашего успеха проведения коммунизма в России». Он не передал Потапову никаких документов, за исключением собственной фотографии. Однако они договорились поддерживать связь по английским и китайским шифрам [цит. по: 7, с. 55; см. также: 39, с. 170]. Потапов отмечал, что, несмотря на негативное отношение к коммунизму, группа Сунь Ятсена выступает за сближение с советской Россией [30, л. 31; 31, л. 34].

Лидер Гоминьдана Сунь Ятсен со своими советниками жил в тот момент в Шанхае в своеобразной «полуэмиграции». В Китае с 1917 г. шла гражданская война между северными и южными военными группами (так называемыми «милитаристами»). Сунь Ятсен был избран руководителем Юга, но южные генералы принудили его отказаться от реальной власти. 20 мая 1918 г. Сунь Ятсен стал лишь одним из семи членов Административного совета правительства, которое было образовано в Гуанчжоу (Кантоне) [53, с. 417]. Вскоре, однако, он покинул этот орган из-за разногласий с гуансийскими генералами во главе с Лу Юнтином и уехал в Шанхай. В 1920 г. к нему присоединились и двое других членов совета, и между группой в Шанхае и Южным правительством в Кантоне наступил разрыв. «Шанхайцы» во главе с Сунь Ятсеном пытались вести сепаратные переговоры с Северным правительством в Пекине, но эти попытки закончились безрезультатно. Они взяли курс на свержение группы Лу Юнтина в Кантоне [54, с. 426].

Интересы Сунь Ятсена в этой обстановке оставались вполне определенными. Ни тогда, ни позднее он не намеревался ни внедрять в Китае ту модель, которая осуществлялась в советской России, ни способствовать утверждению какой-либо иной формы коммунизма. Как вспоминал позднее эмиссар Коминтерна С.А. Далин, который встречался с китайским лидером в 1922 г., тот заявил ему: «Я дам вам самый дикий, горный уезд, не развращенный современной цивилизацией. Жители его принадлежат к народности мяо. Они более способны воспринять коммунизм, чем жители наших городов, где современная цивилизация сделала их противниками коммунизма. Вот в этом уезде организуйте Советскую власть, и, если ваш опыт будет удачным, я применю эту систему для всего Китая» [11, с. 125]. Не исключено, что нечто подобное он завил и Потапову. Такое явно ехидное отношение к коммунизму не мешало Сунь Ятсену - весьма прагматическому политику, нередко шедшему на почти беспринципные альянсы - стремиться получить помощь от советской России. В том же 1920 г. он обсуждал возможности сотрудничества с полковником М.П. Поповым, который приехал в Китай с мандатом, выданным «красными» властями Амурской области. По свиде- 
тельству Сокольского, Сунь Ятсена интересовала возможность получить поддержку его военным планам. Однако «Попов пришел к выводу, что планы д-ра Суня неосуществимы. Он сказал, что большевики устали от войны и хотят мира. Он охарактеризовал д-ра Суня как старомодного милитариста, который не видит иного пути спасения своей родины, кроме военного» [16, c. 156]. Тем более не приходилось ожидать такой помощи от Потапова!

Но если вожди Гоминьдана Сунь Ятсен или Тан Шаои и не воспринимали генерала Потапова всерьез, то этого нельзя сказать о корейских и китайских радикалах, которые в это время группировались в Шанхае.

Тесные отношения сложились у Потапова с корейскими активистами в Шанхае. После антияпонского восстания 1919 г. в Корее в этом городе разместилось эмигрантское «Временное правительство Республики Корея», в котором пост премьер-министра до 1921 г. занимал приехавший из Владивостока лидер корейских социалистов Ли Донхви. В 1921 г. он объявил о преобразовании своей партии в коммунистическую. Его группа с 1919 г. поддерживала связи с большевиками и Коминтерном через российский Дальний Восток. Сокольский сообщал, что Потапов находился в близких дружеских отношениях с корейцем «мистером Лю» [16, с. 155]. Возможно, что именно через корейских друзей генерал свел знакомство и с китайскими социалистами, в первую очередь из организации «Датун дан».

В справке, составленной к документам генерала Потапова, переданным в Коминтерн, «Датун дан» («Партия великой гармонии», или «Партия великого единения») $)^{3}$ именуется единственной «строго революционной, с коммунистическим уклоном, но национальной в то же время и антияпонской» $[15, \text { л. } 4]^{4}$. Об этой организации до сих пор известно очень мало, и именно отчеты генерала служат одним из основных источников информации о ней. По данным, которые приводил Потапов, «Датун дан» была создана после 1916 г. на Юге Китая и позднее реорганизовалась. В нее вошли такие объединения и группы, как ассоциации, созданные китайскими студентами, обучавшимися в США и Японии, «Новоазиатское общество», научные, культурные, религиозные и философские общества и союзы, остатки индийских революционных организаций, разгромленных британскими властями ${ }^{5}$, корейские

3. "Датун» - «великая гармония», древний китайский термин, обозначавщий идеальное справедливое общественное устройство. В начале 1920-х годов он переводился иногда как «соииализм», «коммунизм», «великое единение», «интернациональный сочиализм», «мировое сообщество» и даже «Интернационал».

4. Позднее советский эмиссар В.Д. Виленский-Сибиряков характеризовал "Датун дан» как партию социалистическую, но постепенно проникавщуюся коммунистическими идеями [6, с. 3590].

5. Шанхай и другие портовые города Китая с начала Первой мировой войны служили базой для операций индийского революционного движения «Гадар», которое 
революционные группы, а также «коммунистические» группы (Потапов воспроизводил их названия как «Куан-И» и «Ли-Рен-Ие»). «Датун дан» действовала как тайный союз и работала в Китае, Японии, Нидерландской Индии, Индокитае, Сиаме и Австралии. Через своих видных активистов партия оказывала влияние на союзы студентов, профессоров, учащихся, вернувшихся из-за границы, мелких торговцев и на рабочие союзы. Она создала также тайную военную организацию для борьбы с Пекинским правительством, Японией и другими иностранными державами. Военная организация пыталась наладить связи с партизанскими и повстанческими группами на Севере Китая (хунхузами) и вела агитацию в войсках [30, л. 26-29]. Кроме того, Потапов упоминал о том, что к «Датун дан» был близок и генерал Чэнь Цзюнмин, речь о котором пойдет ниже [32, л. 23].

Студент-социалист Хуан Цземинь (Хуан Цзюэ), ставший после возвращения в Китай из Японии в 1918 г. одним из фактических лидеров партии, пытался привлечь в нее социалистов всех направлений, включая анархистов, а иногда и сам именовал себя анархистом [49, с. 268-269]. Программа «Датун дан» провозглашала «человеческое равенство и мировую гармонию» и предусматривала борьбу с любыми милитаристами и военными правительствами, созыв национальной конференции для решения всех государственных вопросов или с целью поднять простой народ на революцию. Во внешнеполитической области партия выступала за отмену всех неравноправных договоров Китая с другими государствами и борьбу с империалистическим господством в Корее, Индии, Вьетнаме, на Тайване и т.д. [49, с. 265-266]. Организация пользовалась влиянием в окружении Сунь Ятсена, Национальном союзе студентов и в рабочих кругах. Почти все ее члены состояли в рабочих или студенческих союзах. Так, сам Хуан Цземинь стал одним из лидеров рабочих организаций, которые создавались в Шанхае при поддержке Гоминьдана: Всекитайской промышленной федерации (февраль 1919 г.), Всекитайского общества гармонии и прогресса труда (август 1919 г.) и Национального альянса рабочих и крестьян (октябрь 1919 г.). Он был избран также председателем Союза рабочих Китая, сформированного в 1920 г. Промышленной федерацией, союзом электриков и тремя другими рабочими организациями. Генеральным секретарем Союза рабочих в марте 1920 г., по приглашению Хуан Цземиня, ненадолго стал будущий коммунист Чжан Готао [49, с. 256257, 271-272]. Все эти организации, вместе со студенческими союзами,

стремилось организовать восстание в Индии и освободить ее от колониального господства Великобритании. Сотрудничая с германскими представителями, индийские революционеры переправляли в Индию активистов и оружие. Многие деятели движения остались в Китае после войны, сотрудничая с Гоминьданом и китайскими коммунистами [см.: 51]. 
которые находились под влиянием «Датун дан», шли в первых рядах антияпонских протестов и забастовок в Шанхае весной-летом 1919 г. и в январеапреле 1920 г., всеобщих стачек студентов и т.д. В 1920 г. Хуан Цземинь готовил создание Коммунистической партии в Китае, с опорой на структуры «Датун дан» и в тесном сотрудничестве с корейскими коммунистами в Шанxae $[49 \text {, с. } 272,277]^{6}$.

«Агентура общества очень широкая и охватывает не только всю Азию и Японию, но и Ост-Индию и Полинезию, - докладывал позднее в Москве Потапов. - Недостаток собираемых пожертвованиями средств задерживает развитие и более интенсивную деятельность. В члены общества принимаются лица, известные прочностью своих политических убеждений. При вступлении проходят через ритуал. Существуют лозунги для определений своих от чужих и отзывы. За нарушение устава Общества - жестокая кара. Организация Общества очень прочная, и захват части руководителей или членов не может отразиться на работе всей организации...» [30, л. 29].

Генерал Потапов завязал тесные отношения с лидерами «Датун дан» и был даже принят в состав ее ЦК. Хуан Цземинь вручил ему официальный мандат партии, посвящение и обращение от имени Союза рабочих Китая к правительству советской России. Последний документ содержал ответ на обращение к китайскому народу и правительствам Южного и Северного Китая, принятое Совнаркомом РСФСР 25 июля 1919 г. [текст обращения см.: 27]. Потапов передал текст этого обращения «Датун дан», и оно было впервые предано огласке в Китае в печатном органе этой организации [30, л. 27]. Поблагодарив за обращение, которое «вызвало чрезвычайную радость китайского народа, очень тронуло и вызвало сочувствие всего рабочего мира», лидеры Союза рабочих заявляли: «Китайский народ в настоящее время еще находится в угнетении своих и иностранных капиталистов, но надеется на Вашу чистосердечную помощь, которую Вы окажете ему в силу своего искреннего сочувствия, чтобы сбросить ярмо внутренних и внешних капиталистов под Вашим справедливым руководством, а это вся наша надежда» [25, л. 7].

6. Однако ведущий активист организации Яо Цзобинь, приехавщий в 1921 г. в Москву вместе с корейскими делегатами и выступавщий от имени "Коммунистической партии Востока», не добился признания от Коминтерна. Его представительство было оспорено членами Китайского союза сочиалистической молодежи, которые учились в Москве. Яо был арестован и отправлен в ссылку в Сибирь. Представители «офиииальной» Коммунистической партии Китая обвинили Яо Цзобиня в том, что он не член компартии, а обманщик и «подльй предатель китайского студенчества во время второй всекитайской забастовки студенчества» [см.: 18, л. 9]. 
Вернувшись позднее в Россию, генерал Потапов рекомендовал советским властям сделать ставку на «Датун дан». Однако советские эмиссары в Китае его мнения не разделяли. «Весной с[его] г[ода] прибывшие из Владивостока в Китай социалисты ${ }^{7}$ пытались убедить меня в нецелесообразности пропаганды идей Советской России для китайского народа ${ }^{8}$ и тем более протестовали против моей поддержки общества Да-Тонг-Данг, к которому стали присоединяться китайские социалисты», - жаловался позднее генерал в Москве. По его словам, эмиссары начали против него агитацию, «ссылаясь на якобы имеющиеся у них полномочия от Ленина», и это «повредило работе» [30, л. 31].

Стоит отметить, что, несмотря на свои симпатии к «Датун дан», Потапов контактировал в Шанхае и с другими политическими лидерами. Среди тех, с кем он поддерживал связи или встречался, были деятели Гоминьдана Чэнь Цзяньай, Дай Цзитао, деятели рабочего движения Цао Ябо (один из секретарей Сунь Ятсена) и Яо Цзобинь [46, с. 90] и даже правые деятели генералы Ван Итан (представитель клуба «Аньфу») и Гао Шипин (бывший начальник штаба военного губернатора маньчжурской провинции Гирин) [16, с. 155].

В конце апреля 1920 г., покинув Шанхай, Потапов отправился дальше на юг. Он решил посетить район, который в тот момент считался своего рода центром китайской революции - юг прибрежной провинции Фуцзянь.

Часть Фуцзяни с центром в городе Чжанчжоу была в 1918 г. занята силами Гуандунской армии под командованием генерала Чэнь Цзюнмина,

7. В апреле 1920 г. Иностранный отдел при Владивостокском отделении Дальневосточного бюро РКП (б) направил на работу в Китай троих коммунистов: уполномоченного Г.Н. Войтинского («Григорьева») и его помощников - выпускника Восточного института Титова и корейского эмигранта Валентина Кима («Серебрякова»). «Этим было положено начало нашей планомерной организачионной работе в странах Дальнего Востока», - указывалось в докладе Секиии восточных народов при Сиббюро ЦК РКП (б) Исполкому Коминтерна [13, л. 39]. При помощии марксиста Чэнь Дусю Войтинский организовал в Шанхае коммунистический кружок, в котором до лета 1920 г. сначала участвовали также анархисты, сочиалисты и другие радикалы. В 1921 г. шанхайский кружок стал ядром Коммунистической партии Китая (КПК).

8. Задачи большевистской деятельности в Китае и других странах региона были определены на заседании Восточного бюро при Сибирской миссии по иностранным делам 18 мая 1920 г. планировалось установить связи с «револючионно-демократическими» и «интернационально-социалистическими» течениями и партиями или способствовать их формированию; организовать и объединить на местах коммунистические или по крайней мере «резко революиионно-оппозиционные» ячейки; содействовать «туземным револючионным организачиям в деле приобретения оружия и других предметов, необходимых для работы организачий»; оборудовать типографии и т.д. [34, л. 1-2]. Таким образом, российские больщевики собирались вначале оформить широкие социалистические объединения, а затем выделить в них пробольшевистское крыло. 
выбившими оттуда войска северных генералов. Чэнь Цзюнмин открыто заявлял о своих социалистических убеждениях. Член партии Сунь Ятсена, он в последние годы Цинской монархии тесно сотрудничал с группой заговорщиков во главе с «душой китайского анархизма» Шифу (Ли Сыфу), которая планировала покушения на лидеров императорского режима. После Синьхайской революции и свержения монархии в 1911-1912 гг. он занимал пост военного губернатора провинции Гуандун, но был смещен в 1913 г. В 1917 г. он признал Южное правительство и возглавил Гуандунскую армию [биографию генерала Чэнь Цзюнмина см.: 42].

Старинный город Чжанчжоу, в котором размещалась штаб-квартира генерала Чэня, находился в плодородной, цветущей сельскохозяйственной местности, напоминающей «огромный сад». Расположенный на берегу небольшой приливной реки, город в конце XIX в. простирался в пределах старых стен всего на 7 км, но охватывал обширные и густонаселенные пригороды, поглотив соседние городки. «Сам город, - описывали Чжанчжоу географы Э. и О. Реклю, - чистый, хорошо ухоженный; настоящее удовольствие передвигаться по его улицам, некоторые из которых почти заслуживают имя бульваров: 20 метров шириной, хорошее мощение из гранита...» [52, с. 400].

Созданная Чэнь Цзюнмином военно-гражданская администрация осуществила в «Районе защиты конституции Южной Фуцзяни» (Миньнань хуфа цю) ряд прогрессивных реформ. Были проведены работы по благоустройству Чжанчжоу, и город приобрел современный облик: снесены старые городские стены, построены новые улицы и дороги, разбиты два общественных парка. Начато строительство дорог, соединявших город с провинцией. Были приняты меры по улучшению санитарно-гигиенического положения, налажена медицинская служба и организована эффективная борьба с эпидемией оспы [42, c. 86-87]. В парке установили каменный обелиск с надписью «Свобода, равенство, братство, взаимопомощь».

Приехав в Чжанчжоу, Потапов встретился с генералом Чэнем и обсуждал с ним вопросы революции и сотрудничества с советской Россией. Вот как он сам описывал свои впечатления от бесед с китайским революционным лидером: «Ген[ерал] Чен-Кван-Мин, главнокомандующий всеми вооруженными силами, действующими против Пекинского правительства, независимый, с падением Кантона генерал-губернатор Фукиенской провинции (Фуцзяни. $B$. Д.), уроженец Квантунской области (Гуандуна. - В. Д.), революционный деятель, известный публицист и издатель, высоко уважаемый не только на его родине, но и во всем Южном Китае и широко популярный по всей территории республики, лучший из современных военачальников, ведет крайне скромный образ жизни и проводит коммунистические идеи в семье и среди своих приверженцев, сам обрабатывает землю, всюду устраивает библиотеки и создал много школ, в которых ввел новую систему обучения. Его войска 
являются лучшими в Китае. Чанджоу [Чжанчжоу] является самым благоустроенным городом в Китае (из закрытых для иностранцев), куда даже всюду проникающие японцы ген[ералом] Чен-Кван-Мин смело ограничиваются в их правах торговли. Кроме миссионеров и приглашенных им на службу иностранцев, иноземных обитателей не значится. В беседах со мной Чен-КванМин неоднократно высказывал свое мнение, что китайский народ в целях возрождения должен пройти через ряд страданий, что только кровавая революция, которая бы смела все изжившие предрассудки, могла бы создать новый Китай на наших началах. Не возражает против советской организации, и отношение его к Русской революции вполне определяется представленным мною его письмом к В.И. Ленину “как Учитель” (так в тексте. - В.Д.) и посланием его к китайскому населению в России» [32, л. 22-23].

Письмо Чэнь Цзюнмина к Ленину, которое китайский генерал вручил Потапову, представляет собой действительно любопытный документ. Оно демонстрирует как расплывчатость взглядов китайских радикалов, сочетавших различные анархистские и социалистические элементы, так и их смутные представления о том, что же в действительности происходило в Советской России. Генерал Чэнь выражал свои «радость и счастье» в связи с «успехами революции» в России и благодарил за обращение Совнаркома 1919 г. Он заявлял: «Все смуты и бедствия современного человечества исходят из принципов государственности и капитализма. Только разрушив государственные границы, мы прекратим мировые войны, и только разрушив капитализм, мы можем думать о равенстве человечества». Китай, ставший благодаря «высокому принципу человечности» «центром цивилизации на Дальнем Востоке», подвергся «грабежу насильников-грабителей извне, а внутри угнетается деспотизмом» - поэтому он не смог «организовать осуществление принципов человечности в мире». Зато создавшаяся «на принципах большевизма новая Россия открывает новую эру мировой истории», утверждал Чэнь Цзюнмин. Упомянув о беседах с Потаповым, который рассказал «о положении новой России и распространении путей самоопределения», генерал Чэнь выражал надежду на то, что Россия окажет «помощь нашему грядущему новому революционному движению в его различных видах». Китайский народ «достигнет самоопределения», сбросит иго деспотизма и «ярмо капитализма» и создаст «новый Китай». Чэнь Цзюнмин предлагал в будущем союз с Советской Россией: «Новый Китай и новая Россия пойдут рука об руку, как добрые любящие друзья». Он обещал также сотрудничество в осуществлении мировой революции: «...Я уверен в том, что большевизм несет благовестие человечеству, - писал генерал Чэнь. - Я хочу приложить все силы к распространению этих принципов. Наша миссия в том, чтобы перестроить не только Китай, но и всю Восточную Азию» [29]. Помимо 
письма к Ленину, Чэнь Цзюнмин вручил Потапову обращение к китайским рабочим, проживающим в России.

Послание, адресованное китайским генералом лидерам Советской России и дошедшее до них много месяцев спустя, когда политическая ситуация в Китае уже изменилась ${ }^{9}$, было не просто свидетельством церемониальной вежливости. Чэнь Цзюнмин неоднократно искал сближения с Советской Россией. Так, он направлял своих представителей в Тяньцзинь для установления контактов с работавшими там русскими - сторонниками Советской России; связи с ними поддерживались и через радикально настроенных студентов, приезжавших в Чжанчжоу из Северного Китая [14, л. 37-38].

Если верить утверждениям Потапова, то его сотрудничество с Чэнь Цзюнмином в период пребывания в Чжанчжоу было весьма тесным. Он даже помогал китайскому революционному лидеру в составлении прокламаций и воззваний.

Помимо генерала Чэня, Потапов встречался с китайскими анархистскими активистами, которых Чэнь пригласил в Южную Фуцзянь для постановки работы в сфере образования, агитации и издательского дела. Чэнь Цзюнмин не был анархистом: он глубоко уважал анархизм, но заявлял, что не откажется от власти, чтобы ее не захватили недостойные люди и реакционеры [42, c. 90-91]. В 1919 г., по приглашению генерала Чэня, в Чжанчжоу прибыли Лян Биньсянь, Лю Шисинь, Ю Кэшуй, Сюй Чжэньфэн и другие анархисты во главе группы учителей, литераторов, печатников и механиков; в 1920 г. к ним присоединились и другие [42, с. 89]. Лян Бинсянь уговорил Чэнь Цзюнмина учредить специальное Бюро по вопросам образования при штаб-квартире Гуандунской армии и был назначен его главой. Новое учреждение, как вспоминал позднее Лян, немедленно созвало специальную конференцию с участием учителей, администраторов и директоров средних и старших школ. Администрация Южной Фуцзяни открывала новые начальные и средние школы, поддерживала работу педагогического колледжа и других учебных заведений и старалась расширить доступность полного среднего и высшего образования для широкого круга студентов [42, с. 88-89]. Анархистыстуденты из Пекина, приехавшие в Фуцзянь в марте 1920 г. специально для того, чтобы изучить реформы в провинции, в статье, опубликованной в еже-

9. Осенью 1920 г., по договоренности с Сунь Ятсеном, армия Чэнь Цзюнмина покинула Фуизянь и вторглась в провиниию Гуандун, где свергла власть гуансийских генералов. Генерал Чэнь занял пост губернатора провинции и военного министра, но в 1922 г. вступил в конфликт с Сунь Ятсеном, поскольку выступал за федерализацию Китая и против военного похода на Север. Разгромленный при помощи южных генералов, он в 1925 г. бежал в Гонконг. Основанная им в 1927 г. Китайская партия стремления к справедливости с 1949 г. участвует в государственных органах КНР. 
недельнике Пекинского университета, с восторгом называли генерала Чэня «человеком, преданным революции», а мероприятия в сфере образования хорошими, как в «эпоху коммунизма» [45, с. 82$]$.

Анархисты не только возглавили культурно-просветительскую работу в Южной Фуцзяни, но имели также возможность открыто пропагандировать свои идеи, пользуясь фактической поддержкой со стороны генерала Чэня (если речь не шла об антимилитаристской агитации). В апреле 1920 г. американский консул в Амое сообщал, что в Чжанчжоу широко распространяется анархистская пропаганда. Генерал даже лично вручил анархистскую брошюру одному из иностранных посетителей $[44$, с. 150$]$.

Анархисты, по существу, возглавляли агитационно-пропагандистскую и просветительскую работу в провинции. По оценке советского эмиссара Виленского, в фуцзяньском городе были «собраны лучшие силы страны, революционно настроенные. Пекинский союз учащихся, Пекинский университет и северные союзы учащихся командируют туда время от времени своих представителей на помощь генералу Ченю в его работе. Спустя некоторое время эти представители возвращаются на Север вполне подготовленными агитаторами. По отзывам побывавших в Чжанчжоу, там прекрасно поставлен так называемый Образовательный отдел, организация, занимающаяся главным образом устной и печатной пропагандой социалистических учений <... Издание газет в Чжанчжоу также имеет главной целью пропаганду социалистических учений. В программе училища в Чжанчжоу введено преподавание социализма. Чжанчжоу является для революционной молодежи Китая и китайских социалистов местом паломничества» [6, с. 3591].

Анархистам было доверено также издание официального органа - газеты «Миньсин» («Звезда Фуцзяни»). Она начала выходить 1 декабря 1919 г. в Чжанчжоу, 2 раза в неделю, а с 1 января 1920 г. - также и ежедневно. Официально ею руководили лично Чэнь Цзюнмин, написавший манифест с изложением ее целей и задач, который был опубликован в первом номере за 1920 г. Согласно этому программному документу, газета призвана была распространять идеалы свободы, отвергая классовые различия в пользу равенства и конкуренцию - в пользу взаимопомощи [42, с. 86]. Фактически издание возглавлял Лян Бинсянь. Газета распространялась также в Пекине и Шанхае. Редакция размещалась в благоустроенном городском саду, рядом с «Образовательным отделом». «Сотрудники редакции составляют брошюры и прокламации революционного характера, которые раздаются бесплатно всем жителям Чжанчжоу и рассылаются в глубь страны» [6, с. 3591]. Анархисты организовывали в Чжанчжоу митинги и встречи, провели общенациональный конгресс Союза объединенного студенческого движения [47, с. $179 ; 50$, c. 424], выступали на демонстрациях и праздновании 1 мая, распространяли 
сотни тысяч копий листовок и воззваний... [14, л. 38; 6, с. 3591-3593; 37, c. 122].

Китайские анархисты проявляли естественный интерес к российской революции, но также не очень хорошо представляли себе, что происходит у северных соседей. Первые отклики на революционные события в России, которые появились в марте 1918 г. на страницах издававшегося в Шанхае анархистского журнала «Лаодун», трактовали идеологию Октября 1917 г. как анархо-коммунистическую $[47$, с. $165 ; 44$, с. $177-178 ; 37$, с. 142-143]. Вскоре стало понятно, что большевики - отнюдь не анархисты, но руководствуются идеями марксизма. Тем не менее китайские анархисты, которые в конце 1910-х - начале 1920-х годов пользовались прочным влиянием в рабочих союзах Гуанчжоу и Хунани, среди студенчества Пекина и т.д., полагали, что российская революция в любом случае открывает дорогу к будущему установлению свободного анархистского общества. В статье, опубликованной Лян Бинсянем в чжанчжоуской «Миньсин», отмечалось, что большевизм отличается от анархизма и синдикализма Индустриальных рабочих мира. Тем не менее, автор подчеркивал, что эти течения ставят в центр человека труда и стремятся, чтобы все люди стали трудящимися, хотя методы у них и разные [50, с. 421]. В 1919-1920 гг. анархисты и марксисты в Китае нередко входили в одни и те же организации («Общества по изучению социализма», «Социалистические лиги» и др.) [49, с. 239-241; 44, с. 201; 46, с. 163; 37, с. 144-145; 43 , с. $375 ; 41$, с. $91 ; 55$, с. 20], а пекинские анархисты имели тесные связи с поддерживавшими большевиков русскими преподавателями университетов Пекина и Тяньцзиня.

Генерал Потапов несколько раз встречался и беседовал с китайскими анархистами и социалистами в редакции фуцзяньской газеты «Миньсин». Он заявил им: «Если вы понимаете социализм и признаете необходимость социальной революции, то каким бы путем вы ни шли и какое бы действие ни предпринимали, вы - наши друзья, друзья русских большевиков. Поэтому мы должны работать вместе и помогать друг другу. Советское правительство хочет дружить со всеми революционерами в мире, особенно в азиатских странах» [49, с. 164]. Однако, как вспоминал Лян Бинсянь, их дискуссии продемонстрировали коренные различия во взглядах. Сотрудники редакции объяснили гостю, что свобода для них важна, как сама жизнь, и потому они отстаивают право на свободу слова и выражения мнения: «...Мы восхищаемся свершениями русской революции, но не согласны с нарушением человеческих прав после того, как она добилась успеха». В «Миньсин» была опубликована статья с критикой советской конституции, и она отражала позицию большинства китайских «либертарных социалистов». Когда Потапов возразил, что ограничения свободы необходимы для подавления контрреволюции, китайские собеседники ответили ему, что не боятся возрождения контррево- 
люции при республике. «Что же касается будущего, мы верим в совершение социальной революции для достижения социальной справедливости. Когда социальная справедливость будет достигнута, народ поддержит ее от всего сердца, и никакой злодей не сможет разрушить ее... Но если бы мы применили силы разрушения для подавления свободы, то сами стали бы контрреволюционерами» [цит. по: 42, с. 93]...

Из Фуцзяни Потапов направился дальше на Юг. Он намеревался отплыть в Европу и вернуться в Россию. По дороге в Гонконге генералу удалось встретиться с начальником Генерального штаба правительства Южного Китая - генералом Ли Лецзюнем, одним из лидеров юньнаньской военной группировки. После беседы китайский деятель передал Потапову письмо, адресованное советскому правительству. Оно было выдержано в куда более сдержанном и осторожном тоне, нежели послание Чэнь Цзюнмина. Тем не менее и в нем высказывалось стремление «завязать связь и войти в сношения с русским народом и его представителями и установить прочные сношения». Выразив интерес к «эволюции русского народа», которая ведет «неуклонно к поддержке правительства народного, к управлению самим народом», генерал Ли заверял советских лидеров: «Китай вдохновляется вашей программой». Ни о каком упразднении государства, границ или капитализма в его обращении, разумеется, не было и речи. Ли Лецзюнь осторожно информировал, что китайские руководители «были бы польщены, получив изложение взглядов вашего правительства. Мы поспешим их изучить и затем подвергнуть вниманию наших братьев» [26]. С отъездом из Гонконга в Европу китайские приключения русского генерала закончились.

В начале ноября 1920 г. Потапов, наконец, добрался до Риги. Явившись в редакцию местной русской газеты «Сегодня», он предложил журналистам взять у него интервью. На газетчиков он произвел впечатление «не то психически больного человека, не то ловкого авантюриста». Судя по их беседе, генерал откровенно занимался саморекламой, рассказывал небылицы и одновременно, по-видимому, проводил своего рода политический зондаж настроений эмиграции. По его словам, после приезда в Европу, он был арестован в Лондоне в связи с тем, что «гуляя в парке с Каменевым ${ }^{10}$, при встрече познакомил с ним Ллойд-Джорджа, который был настолько очарован Каменевым, что пожелал вступить в деловые связи с Советской Россией». Характерно, что Потапов заявил эмигрантской газете, будто не знал, что Каменев является большевиком, а иначе бы «ни за что не познакомил его

10. Член Политбюро РКП (б) Л.Б. Каменев в июле-сентябре 1920 г. возглавлял советскую миссию в Великобритании, которая вела переговоры о заключении торгового договора. Он и другой руководитель миссии Л.Б. Красин были приглашены к британскому премьер-министру Д. Ллойд-Джорджу 4 августа 1920 г. 
с Ллойд-Джорджем». По его словам, он помнил Каменева как члена Петроградского Совета в 1917 г., когда он сам был якобы «командующим Петроградским округом». Позднее, рассказал генерал, его арестовали в Данциге «французские сыщики» - «в отместку за то, что он сражался против Колчака и способствовал его низложению».

В качестве доказательств своей антиколчаковской борьбы Потапов продемонстрировал журналистам сибирские и шанхайские газеты («Шанхайский вестник»), в которых были опубликованы его воззвания - «приказы». В одном из них, где перечислялись все его заслуги и награды, генерал объявлял себя преемником Керенского и «приказывал» населению «свергать узурпатора и диктатора Колчака».

Показав мандаты на китайском языке, Потапов заявил, что он является «единственным законным представителем 1 миллиона китайских рабочих», но «этим правом бессовестно овладел Ленин». В любой момент, пригрозил генерал, он может дать радиограмму в Пекин и двинуть на Москву миллионную армию, которая «сметет московских узурпаторов». Такие речи весьма сильно контрастировали с его заявлениями в Китае и позднее в России о приверженности Советской власти!

В Латвии Потапов, по его словам, собирался организовать «великорусское движение», на что якобы получил согласие и латвийских властей, и советского дипломата А.А. Иоффе, и представителей русской социалистической эмиграции Н.Д. Авксентьева и О.С. Минора. Он контактировал с русскими общественными деятелями в Риге и представителями белоруской военно-дипломатической миссии, занимался разоблачением «врангелиады» и провозглашал свое намерение уехать в Туркестан, где у него якобы были имения, а семью переправить в Латвию. В конце концов, наделав шума в Риге, генерал в том же ноябре 1920 г. отправился в Петроград вместе с женой советского торгового представителя в Латвии Я. Ганецкого [23].

Приехав в Советскую Россию, генерал, как уже говорилось, передал все документы в НКИД и выразил полную лояльность советской власти. Об отношении к нему свидетельствует такой любопытный эпизод. В Петрограде Потапов обнаружил, что в его старой квартире проживают уже новые жильцы, и представители НКИД вмешались, чтобы добиться возвращения его жилья и части личного имущества. При этом в письме наркомата подчеркивалось, что «деятельность Потапова признана Советской властью крайне полезной» $[20, \text { с. } 16]^{11}$. Вскоре бывший генерал был переведен на службу в Москву. Здесь его следы вскоре теряются. По некоторым сведениям, он был

\footnotetext{
11. Характерно, что М.Б. Лебина, как и многие другие авторы, принимает на веру утверждение, будто Потапов был отправлен на Дальний Восток в декабре 1917 2. большевистским НКИДом.
} 
арестован в 1924 г. [28, с. 270]. Выяснение его дальнейшей судьбы - дело новых исследователей.

\section{Библиография}

1. Англо-бурская война 1899-1902 годов глазами российских подданных. М.: Издатель И.Б. Белый, 2012. Т. 6.404 с.

2. Баландин Р.К. Мифы революции 1917 года. М.: Вече, 2007. 368 с.

3. Будберг А. Дневник барона Алексея Будберга // Архив русской революции. Берлин: Слово, 1923. Т. ХІІ. С. 197-290.

3 а. Будберг А. Дневник барона Алексея Будберга // Архив русской революции. Берлин: Слово, 1924. Т. ХІІІ. С. 197-312.

4. Будберг А. Дневник белогвардейца. Минск; М.: Харвест; АСТ, 2001. 336 с.

5. Буржуазия и помещики в 1917 году. Частные совещания членов Государственной думы. Л.: Партийное издательство, 1932. 328 с.

6. Виленский (Сибиряков) В. Накануне образования коммунистической партии в Китае // Коммунистический Интернационал. 1920. № 16. С. 3585-3595.

7. ВКП (б), Коминтерн и национально-революционное движение в Китае. Документы. М.: АО «Буклет», 1994. Т. 1. 1920-1925. 768 с.

8. Ганин А.В. Генштабисты и Февральская революция // Февральская революция: Проблемы истории и историографии. СПб.: ЛЭТИ, 2017. С. 208-264.

9. Ганин А.В. Корпус офицеров Генерального штаба в годы Гражданской войны 1917 1922 гг. Справочные материалы. М.: Русский путь, 2000. 895 с.

10. Гаспарян А.С. Операция «Трест». СПб.: Прогресс книга, 2017. 347 с.

11. Далин С.А. Китайские мемуары. 1921-1927. М.: Наука, 1982. 382 с.

12. Деникин А.И. Крушение власти и армии. Февраль-сентябрь 1917 г. М.; Берлин: Директмедиа, 2016. 577 с.

13. Доклад Исполкому Коминтерна об организации и деятельности Секции восточных народов при Сиббюро ЦК РКП // РГАСПИ. Ф. 495. Оп. 154. Д. 27. Л. 39-44.

14. Доклад о работе в Китае // РГАСПИ. Ф. 514. Оп. 1. Д. 3. Л. 36-43.

15. Документы из Южного Китая // РГАСПИ. Ф. 514. Оп. 1. Д. 6. Л. 1-4.

16. Донесение об отношениях между местными китайцами, корейцами и большевиками. 22 марта 1920 г. // Крюков М.В. Улица Мольера, 29. Секретная миссия полковника Попова (документальная повесть). М.: Памятники исторической мысли, 2000. С. 155-156.

17. Захаров А. Как Кёнигсберг спас Мемель. Из безумной авантюры сделали героическую эпопею // Новые колеса: Еженедельная общественно-политическая газета. Калининград, 2014. 10 июля. № 402. URL: http://www.rudnikov.com/article.php?ELEMENT_ID=22803 (Дата обращения: 20.03.2018.)

18. Заявление Дальневосточному секретариату Коминтерна от делегата Китайской компартии на III конгрессе Коминтерна т. Сю-сун. 27 сентября 1921 г. // РГАСПИ. Ф. 495. Оп. 154. Д. 81. Л. 9.

19. Курлов П.Г. Гибель императорской России. Воспоминания. М.: Захаров, 2002. 301 с.

20. Лебина М.Б. Повседневная жизнь советского города: Нормы и аномалии. 19201930-е годы. СПб.: Журнал «Нева»; Издательско-торговый дом «Летний сад», 1999. 320 с.

21. Мельгунов С.П. Мартовские дни 1917 года. М.: Айрис-пресс, 2008. 688 с.

22. Миллер В.И. Солдатские комитеты русской армии в 1917 году. М.: Наука, 1974. 318 с.

23. Н.Б. Карьера ген. Потапова // Сегодня. Рига, 1920. 27 нояб. № 261. С. 2. 
24. Николаев А.Б. Государственная дума в Февральской революции. Очерки истории. Рязань: Издатель П.А. Трибунский, 2002. 302 с.

25. Обращение [Союза рабочих Китая] к Российскому рабоче-крестьянскому правительству // РГАСПИ. Ф. 514. Оп. 1. Д. 6. Л. 7-8.

26. Обращение начальника Генерального штаба правительства Южного Китая Ли Лецзюня к советскому народу // Советско-китайские отношения 1917-1957. Сборник документов. М.: Издательство восточной литературы, 1959. С. 49-50.

27. Обращение Совета Народных Комиссаров РСФСР к китайскому народу и правительствам Южного и Северного Китая // Советско-китайские отношения 1917-1957. Сборник документов. М.: Издательство восточной литературы, 1959. С. 42-45.

28. Петров В. (Адамович В.В.). Керенский - душа приказа № 1. Черные страницы из истории Русской революции // А.Ф. Керенский: Pro et contra: Личность и деятельность А.Ф. Керенского в оценке современников: антология. СПб.: Издательство Русской Христианской гуманитарной академии, 2016. С. 265-270.

29. Письмо генерала Чэнь Цзюн-миня к В.И. Ленину // Советско-китайские отношения 1917-1957. Сборник документов. М.: Издательство восточной литературы, 1959. С. 50-52.

30. Потапов А.С. Краткий обзор современных политических партий, обществ и союзов в Китае и отношения их и населения разных частей Китая к РСФСР // РГАСПИ. Ф. 514. Оп. 1. Д. 6. Л. 24-33.

31. Потапов А.С. О докторе Сун-Ет-Сене, бывшем первом президенте Китайской Республики // РГАСПИ. Ф. 514. Оп. 1. Д. 6. Л. 34.

32. Потапов А.С. Современное положение в Китае // РГАСПИ. Ф. 514. Оп. 1. Д. 6. Л. 1923.

33. Потапов Алексей Степанович // Русская армия в Великой войне: Картотека проекта [Электронный pecypc]. URL: http://www.grwar.ru/persons/persons.html?id=2929 (Дата обращения: 20.03.2018.)

34. Протокол № 1-й заседания Восточного бюро при Сибирской миссии по иностранным делам 18 мая 1920 года // РГАСПИ. Ф. 495. Оп. 154. Д. 37. Л. 1-2.

35. Революционное движение в русской армии 27 февраля - 24 октября 1917 года. М.: Наука, 1968. $621 \mathrm{c}$.

36. Соколов Н.А. Предварительное следствие 1919-1922 гг. Сборник материалов. М.: Студия ТРИТЭ; Российский архив, 1998. 463 с.

37. Стабурова Е.Ю. Анархизм в Китае 1900-1921. М.: Наука, 1983. 188 с.

38. Тригуб Г.Я. Деятельность Приморской областной земской управы в качестве временного правительства (январь-декабрь 1920 г.) // Ойкумена. 2006. Вып. 1. С. 44-54.

39. Усов В.Н. Советская разведка в Китае. 20-е годы ХХ века. М.: Олма-Пресс, 2002. $384 \mathrm{c}$.

40. Шишкин В.И. «Один из возмутительнейших эпизодов нашей революции» // Исторический архив. 2007. № 4. С. 70-110.

41. Chinese Society under Communism: A Reader. London; New York: John Wiley \& Sons, $1967.496 \mathrm{p}$.

42. Chen L.H.D. Chen Jiongming and the Federalist Movement: Regional Leadership and Nation Building in Early Republican China. Ann Arbor: Center of Chinese Studies; University of Michigan, 1999. $357 \mathrm{p}$.

43. Chow Tse-tung. The May Fourth Movement: Intellectual Revolution in Modern China. Cambridge: Harvard University Press, 1960. 486 p.

44. Dirlik A. Anarchism in the Chinese Revolution. Berkeley; Los Angeles; London: University of California Press, 1991. 326 p. 
45. Goikhman I. Chen Jiongming: Becoming a Warlord in Republican China // State, Society and Governance in Republican China. Berlin; Münster; Wien; Zürich: LIT Verlag, 2014. P. 77-101.

46. Ishikawa Y. The Formation of the Chinese Communist Party. New York: Columbia University Press, 2013. 503 p.

47. Krebs E.S. Shifu, Soul of Chinese Anarchism. Lanham: Rowman \& Littlefield Publishers, 1998. $291 \mathrm{p}$.

48. Lehovich D.V. White against Red. New York: Norton, 1973. 556 p.

49. Liu Jianyi. The Origins of the Chinese Communist Party and the Role Played by Soviet Russia and the Comintern. A Thesis Submitted for the Degree Ph.D. York: University of York, 2000. $418 \mathrm{p}$. $784 \mathrm{~S}$

50. Müller G. China, Kropotkin und Anarchismus. Wiesbaden: Harrassowitz Verlag, 2001.

51. Ramnath M. Haj to Utopia: How the Ghadar Movement Charted Global Radicalism and Attempted to Overthrow the British Empire. Berkeley; Los Angeles; London: University of California Press, 2011. 332 p.

52. Reclus É., Reclus O. L`Empire du Milieu. Le climat, le sol, les races, la richesse de la Chine. Paris: Librairie Hachette et Co, 1902. 669 p.

53. The Consul General at Canton (Bergholz) to the Secretary of State. 8.04.1920 // The Department of State. Papers Related to the Foreign Relations of the United States. 1920. Vol. 1. Washington: United States Government Printing Office, 1935. P. 416-418.

54. The Consul General at Canton (Bergholz) to the Secretary of State. 17.06.1920 // The Department of State. Papers Related to the Foreign Relations of the United States. 1920. In three volumes. Vol. 1. Washington, 1935. P. 426-427.

55. Wilbur C.M., How J.L. Missionaries of Revolution: Soviet Advisers and Nationalist China, 1920-1927. Cambridge; London: Harvard University Press, 1989. 904 p.

56. Wildman A.K. The End of the Russian Imperial Army. Princeton: Princeton University Press, 1980. Vol. 1. 434 p.

\section{References}

Anglo-burskaja vojna 1899-1902 godov glazami rossijskih poddannyh. Moscow: Izdatel' I.B. Belyj, 2012. Vol. 6. 404 p.

Balandin R.K. Mify revoljucii 1917 goda. Moscow: Veche, 2007. 368 p.

Budberg A. Dnevnik barona Alekseja Budberga // Arhiv russkoj revoljucii. Berlin: Slovo, 1923. Vol. XII. P. 197-290.

Budberg A. Dnevnik barona Alekseja Budberga // Arhiv russkoj revoljucii. Berlin: Slovo, 1924. Vol. XIII. P. 197-312.

Budberg A. Dnevnik belogvardejca. Minsk; Moscow: Harvest; AST, 2001. 336 p.

Burzhuazija i pomeshhiki v 1917 godu. Chastnye soveshhanija chlenov Gosudarstvennoj dumy. Leningrad: Partijnoe izdatel'stvo, 1932. 328 p.

Chen L.H.D. Chen Jiongming and the Federalist Movement: Regional Leadership and Nation Building in Early Republican China. Ann Arbor: Center of Chinese Studies; University of Michigan, 1999. $357 \mathrm{p}$. $496 \mathrm{p}$.

Chinese Society under Communism: A Reader. London; New York: John Wiley \& Sons, 1967.

Chow Tse-tung. The May Fourth Movement: Intellectual Revolution in Modern China. Cambridge: Harvard University Press, 1960. 486 p.

Dalin S.A. Kitajskie memuary. 1921-1927. Moscow: Nauka, 1982. 382 p. 
Denikin A.I. Krushenie vlasti i armii. Fevral'-sentjabr' 1917 g. Moscow; Berlin: Direkt-media, 2016. 577 p.

Dirlik A. Anarchism in the Chinese Revolution. Berkeley; Los Angeles; London: University of California Press, 1991. 326 p.

Doklad Ispolkomu Kominterna ob organizacii i dejatel'nosti Sekcii vostochnyh narodov pri Sibbjuro CK RKP // RGASPI. F. 495. Op. 154. D. 27. L. 39-44.

Doklad o rabote v Kitae // RGASPI. F. 514. Op. 1. D. 3. L. 36-43.

Dokumenty iz Juzhnogo Kitaja // RGASPI. F. 514. Op. 1. D. 6. L. 1-4.

Donesenie ob otnoshenijah mezhdu mestnymi kitajcami, korejcami i bol'shevikami. 22 marta 1920 g. // Krjukov M.V. Ulica Mol'era, 29. Sekretnaja missija polkovnika Popova (dokumental'naja povest'). Moscow: Pamjatniki istoricheskoj mysli, 2000. P. 155-156.

Ganin A.V. Genshtabisty i Fevral'skaja revoljucija // Fevral'skaja revoljucija: problemy istorii i istoriografii. Saint-Petersburg: LJeTI, 2017. P. 208-264.

Ganin A.V. Korpus oficerov General'nogo shtaba v gody Grazhdanskoj vojny 1917-1922 gg. Spravochnye materialy. Moscow: Russkij put', 2000. 895 p.

Gasparjan A.S. Operacija «Trest». Saint-Petersburg: Progress kniga, 2017. 347 p.

Goikhman I. Chen Jiongming: Becoming a Warlord in Republican China // State, Society and Governance in Republican China. Berlin; Münster; Wien; Zürich: LIT Verlag, 2014. P. 77-101.

Ishikawa Y. The Formation of the Chinese Communist Party. New York: Columbia University Press, 2013. 503 p. $291 \mathrm{p}$

Krebs E.S. Shifu, Soul of Chinese Anarchism. Lanham: Rowman \& Littlefield Publishers, 1998.

Kurlov P.G. Gibel' imperatorskoj Rossii. Vospominanija. Moscow: Zaharov, 2002. 301 p.

Lebina M.B. Povsednevnaja zhizn' sovetskogo goroda: Normy i anomalii. 1920-1930 gody. Saint-Petersburg: Zhurnal «Neva»; Izdatel'sko-torgovyj dom «Letnij sad», 1999. 320 p.

Lehovich D.V. White against Red. New York: Norton, 1973. 556 p.

Liu Jianyi. The Origins of the Chinese Communist Party and the Role Played by Soviet Russia and the Comintern. A Thesis Submitted for the Degree Ph.D. York: University of York, 2000. 418 p.

Mel'gunov S.P. Martovskie dni 1917 goda. Moscow: Ajris-press, 2008. 688 p.

Miller V.I. Soldatskie komitety russkoj armii v 1917 godu. Moscow: Nauka, 1974. 318 p.

Müller G. China, Kropotkin und Anarchismus. Wiesbaden: Harrassowitz Verlag, 2001. 784 S.

N.B. Kar'era gen. Potapova // Segodnja. Riga, 1920. Nov. 27. N 261. P. 2.

Nikolaev A.B. Gosudarstvennaja duma v Fevral'skoj revoljucii. Ocherki istorii. Rjazan': Izdatel' P.A. Tribunskij, 2002. 302 p.

Obrashhenie [Sojuza rabochih Kitaja] k Rossijskomu raboche-krest'janskomu pravitel'stvu // RGASPI. F. 514. Op. 1. D. 6. L. 7-8.

Obrashhenie nachal'nika General'nogo shtaba pravitel'stva Juzhnogo Kitaja Li Le-czjunja k sovetskomu narodu // Sovetsko-kitajskie otnoshenija 1917-1957. Sbornik dokumentov. M.: Izdatel'stvo vostochnoj literatury, 1959. P. 49-50.

Obrashhenie Soveta Narodnyh Komissarov RSFSR k kitajskomu narodu i pravitel'stvam Juzhnogo i Severnogo Kitaja // Sovetsko-kitajskie otnoshenija 1917-1957. Sbornik dokumentov. Moscow: Izdatel'stvo vostochnoj literatury, 1959. P. 42-45.

Petrov V. (Adamovich V.V.). Kerenskij - dusha prikaza № 1. Chernye stranicy iz istorii Russkoj Revoljucii // A.F. Kerenskij: Pro et contra: Lichnost' i dejatel'nost' A.F. Kerenskogo v ocenke sovremennikov: antologija. Saint-Petersburg: Izdatel'stvo Russkoj Hristianskoj gumanitarnoj akademii, 2016. P. 265-270.

Pis'mo generala Chjen' Czjun-minja k V.I. Leninu // Sovetsko-kitajskie otnoshenija 1917-1957. Sbornik dokumentov. Moscow: Izdatel'stvo vostochnoj literatury, 1959. P. 50-52. 
Potapov A.S. Kratkij obzor sovremennyh politicheskih partij, obshhestv i sojuzov v Kitae i otnoshenija ih i naselenija raznyh chastej Kitaja k RSFSR // RGASPI. F. 514. Op. 1. D. 6. L. 24-33.

Potapov A.S. O doktore Sun-Et-Sene, byvshem pervom prezidente Kitajskoj Respubliki // RGASPI. F. 514. Op. 1. D. 6. L. 34.

Potapov A.S. Sovremennoe polozhenie v Kitae // RGASPI. F. 514. Op. 1. D. 6. L. 19-23.

Potapov Aleksej Stepanovich // Russkaja armija v Velikoj vojne: kartoteka proekta [Jelektronnyj resurs]. URL: http://www.grwar.ru/persons/persons.html?id=2929 (Data obrashhenija: 20.03.2018.)

Protokol № 1-j zasedanija Vostochnogo bjuro pri Sibirskoj missii po inostrannym delam 18 maja 1920 goda // RGASPI. F. 495. Op. 154. D. 37. L. 1-2.

Ramnath M. Haj to Utopia: How the Ghadar Movement Charted Global Radicalism and Attempted to Overthrow the British Empire. Berkeley; Los Angeles; London: University of California Press, 2011. 332 p.

Reclus É., Reclus O. L`Empire du Milieu. Le climat, le sol, les races, la richesse de la Chine. Paris: Librairie Hachette et Co, 1902. 669 p.

Revoljucionnoe dvizhenie v russkoj armii 27 fevralja - 24 oktjabrja 1917 goda. Moscow: Nauka, 1968. 621 p.

Shishkin V.I. «Odin iz vozmutitel'nejshih jepizodov nashej revoljucii» // Istoricheskij arhiv. 2007. N 4. P. 70-110.

Sokolov N.A. Predvaritel'noe sledstvie 1919-1922 gg. Sbornik materialov. Moscow: Studija TRITJe; Rossijskij Arhiv, 1998. 463 p.

Staburova E.Ju. Anarhizm v Kitae 1900-1921. Moscow: Nauka, 1983. 188 p.

The Consul General at Canton (Bergholz) to the Secretary of State. 8.04.1920 // The Department of State. Papers Related to the Foreign Relations of the United States. 1920. Vol. 1. Washington: United States Government Printing Office, 1935. P. 416-418.

The Consul General at Canton (Bergholz) to the Secretary of State. 17.06.1920 // The Department of State. Papers Related to the Foreign Relations of the United States. 1920. In three volumes. Vol. 1. Washington, 1935. P. 426-427.

Trigub G.Ja. Dejatel'nost' Primorskoj oblastnoj zemskoj upravy v kachestve vremennogo pravitel'stva (janvar'-dekabr' 1920 g.) // Ojkumena. 2006. Vyp. 1. P. 44-54. $384 \mathrm{p}$.

Usov V.N. Sovetskaja razvedka v Kitae. 20-e gody HH veka. Moscow: Olma-Press, 2002.

Vilenskij (Sibirjakov) V. Nakanune obrazovanija kommunisticheskoj partii v Kitae // Kommunisticheskij Internacional. 1920. N 16. P. 3585-3595.

VKP (b), Komintern i nacional'no-revoljucionnoe dvizhenie v Kitae. Dokumenty. M.: AO «Buklet», 1994. Vol. 1. 1920-1925. 768 p.

Wilbur C.M., How J.L. Missionaries of Revolution: Soviet Advisers and Nationalist China, 1920-1927. Cambridge; London: Harvard University Press, 1989. 904 p.

Wildman A.K. The End of the Russian Imperial Army. Princeton: Princeton University Press, 1980. Vol. 1. 434 p.

Zaharov A. Kak Kjonigsberg spas Memel'. Iz bezumnoj avantjury sdelali geroicheskuju jepopeju // Novye koljosa: Ezhenedel'naja obshhestvenno-politicheskaja gazeta. Kaliningrad, 2014. Jul. 10. N 402. URL: http://www.rudnikov.com/article.php?ELEMENT_ID=22803 (Data obrashhenija: 20.03.2018.)

Zajavlenie Dal'nevostochnomu sekretariatu Kominterna ot delegata kitajskoj kompartii na III kongresse Kominterna t. Sju-sun. 27 sentjabrja 1921 g. // RGASPI. F. 495. Op. 154. D. 81. L. 9. 